\title{
Oral hygiene among patients with orthodontic appliances
}

\author{
Igiena orală la pacienţii purtători de aparate ortodontice
}

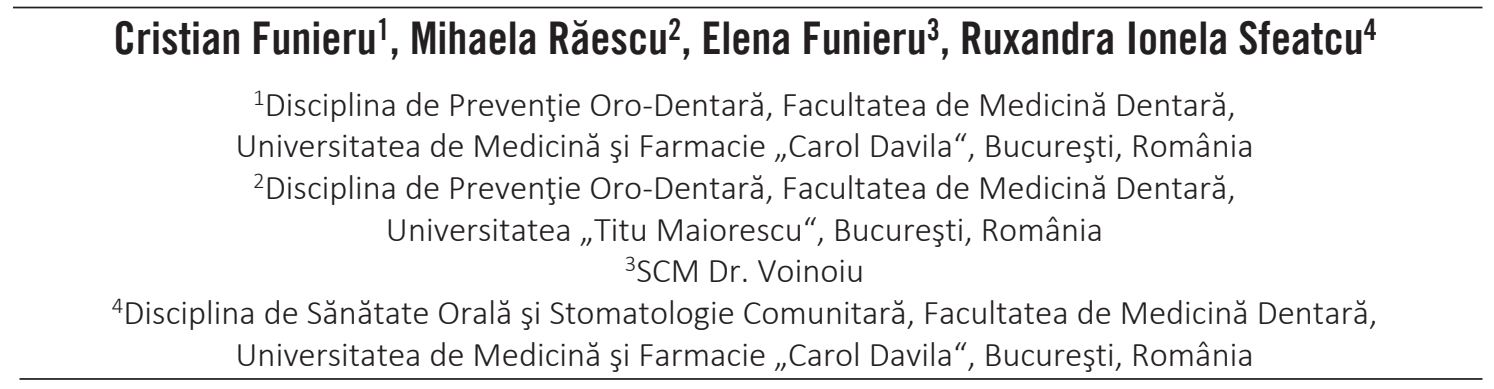

\begin{abstract}
Introduction. The oral hygiene of patients with orthodontic appliances is a process that is quite important for the success of the treatment and often difficult to perform. An important role here is that the dentist and the orthodontist work together and make a good team.

Materials and method. There were investigated two groups of patients (a group of fixed and mobile orthodontic patients and a control group) aged between 10 and 27 years. As methods, the Silness \& Löe Plaque Index and a questionnaire of 5 questions about oral hygiene were used.

Results. Plaque index had higher mean values in patients with orthodontic appliances. It was also found from the questionnaire answers analysis a greater care for oral hygiene among patients in orthodontic treatment.

Conclusion. Additional care for oral hygiene may be the solution for maintaining balance during orthodontic treatment.
\end{abstract}

Keywords: dental plaque, orthodontic appliances, oral hygiene

\section{REZUMAT}

Introducere. Igiena orală a pacienţilor purtători de aparate ortodontice este un proces destul de important pentru succesul tratamentului şi se realizează de multe ori cu dificultate. Un rol important îl constituie aici colaborarea dintre medicul dentist şi specialistul ortodont.

Materiale și metodă. Au fost investigate două loturi de pacienţi (un lot cu pacienţi purtători de aparate ortodontice şi un lot martor, cu pacienţi ce nu au beneficiat de acest tip de tratament) cu vârste cuprinse între 10 şi 27 de ani. Ca instrumente de anchetă au fost folosite indicele de placă Silness \& Löe şi un chestionar cu 5 întrebări despre igiena orală.

Rezultate. Indicele de placă a avut valori medii mai mari la pacienţii purtători de aparate ortodontice. De asemenea, s-a constatat din analiza răspunsurilor chestionarelor o grijă mai mare pentru igiena orală a pacienţilor aflaţi în tratament ortodontic.

Concluzie. O grijă suplimentară pentru igiena orală poate fi soluţia pentru menţinerea echilibrului pe parcursul tratamentului ortodontic.

Cuvinte cheie: placă bacteriană, aparate ortodontice, igienă orală

\section{INTRODUCERE}

Pacientul purtător de aparate ortodontice trebuie să aibă în mod deosebit grijă de igiena sa orală deoarece, față de individul normal, există o serie de elemente suplimentare ce fac această acțiune foarte importantă dar şi dificilă în acelaşi timp. Un prim element ar fi retențiile suplimentare pe care le oferă arcadele dentare naturale din cauza incongruențe- 
lor dento-alveolare, situație prezentă în special la începutul tratamentului ortodontic, precum şi cele ca urmare a retentivităților artificiale - componentele aparatelor ortodontice. Aceste retentivități constituie factori de retenție pentru placa microbiană şi resturile alimentare, ducând astfel la instalarea unui mediu propice dezvoltării bacteriilor şi a instalării cariilor şi inflamației gingivale (1). Unele cercetări efectuate în acest sens au demonstrat selectia unor bacterii şi chiar a unor tulpini speciale ale acestora (Porphyromonas gingivalis cu fimbrii de tipurile II, IV şi V), implicate în patologia gingivitei la aceşti pacienți (2). Pe parcursul tratamentului ortodontic s-au mai constatat atât acumulări de tartru, cât şi creşterea numărului de pungi parodontale, semn că, în absența unei igiene orale corecte, se poate instala şi riscul de boală parodontală (3). Tot în acest sens, un alt aspect care trebuie luat în seamă este faptul că, de cele mai multe ori, vârsta pacienților cu un astfel de tratament este cea a pubertătii şi adolescenței, când incidența afecțiunilor gingivale/parodontale şi vulnerabilitatea la carie dentară sunt mari.

Pentru prevenirea apariţiei bolii parodontale sau a cariilor dentare la pacienții purtători de aparate ortodontice, aceştia trebuie mai întâi să se prezinte la medicul dentist înainte de începerea tratamentului ortodontic, pentru tratamentul cariilor sau al diferitelor forme de boală parodontală, dacă acestea există. Medicul dentist va recurge şi la sigilarea obligatorie a molarilor de 6 ani indemni şi cu relief ocluzal accidentat. După ce a început tratamentul ortodontic, pacientul trebuie instruit pentru o igienă orală riguroasă, care implică, pe lângă simplul periaj personal, de preferabil electric, şi folosirea unor mijloace ajutătoare de curățire (periuțe interdentare, unitufă, superfloss, duş bucal etc.). Pacienţii purtători de aparate ortodontice mobile trebuie să cunoască suplimentar şi regulile de igienizare a acestora, care sunt în mare parte asemănătoare cu cele de igienizare a protezelor dentare mobile.

Scopul acestui studiu este să determine acumularea de placă bacteriană la pacienții aflați în tratament ortodontic (lotul de studiu), precum şi să stabilească care este atitudinea prin care aceştia îşi realizează propria igienă orală.

\section{MATERIALE ŞI METODĂ}

Pentru acest studiu au fost luate în calcul două loturi: unul de studiu de 30 de pacienți, purtători de aparate ortodontice fixe şi mobile, şi un lot martor de 26 de pacienți ce nu se aflau pe parcursul vreunui tratament ortodontic şi nici nu au beneficiat niciodată de acesta. Pacienții au avut vârste cuprinse între 10 şi 27 de ani.

Ca metodă obiectivă de investigare s-a folosit indicele Silness \& Löe. După cum se ştie, protocolul acestui indice nu implică colorarea plăcii dentare, ci doar inspecția, examinarea atentă şi utilizarea sondei parodontale. Se examinează doar placa bacteriană din treimea cervicală şi se atribuie următoarele valori: 0 , când nu există placă; 1 , când există placă microbiană sub forma unui film ce aderă de marginea gingivală liberă şi în regiunea învecinată dintelui (se determină prin palparea suprafeței dentare cu sonda parodontală); 2 , depozite moi în cantitate moderată, ce pot fi observate cu ochiul liber la nivelul şanțului gingival, al marginii gingivale libere sau pe suprafața dentară; 3, depozite moi, abundente la nivelul şanțului gingival, al marginii gingivale libere sau pe suprafața dentară (1).

Un alt instrument de anchetă utilizat, de această dată subiectiv, a fost chestionarul. Acesta a cuprins 5 întrebări cu răspunsuri închise despre realizarea igienei orale. Întrebările chestionarului au fost:

\section{Ce periuță dentară folosiți?}

o manuală

○ electrică

2. Ce mijloace suplimentare de igienă orală (pe lângă periajul dentar) utilizați?
o ața dentară
o periuța interdentară
○ apa de gură
o duşul bucal
$\circ$ altceva.....
○ NU folosesc nimic în plus

3. Vă igienizați cavitatea bucală după mesele luate în timpul zilei?

○ DA, mă spăl pe dinţi

○ DA, clătesc gura cu apă

$\circ \mathrm{NU}$

4. Realizați igienizarea aparatului dentar mobil în fiecare seară? (Întrebare pentru purtătorii de aparate ortodontice mobile)
$\circ$ DA
$\circ \mathrm{NU}$ 
5. Utilizați tablete pentru curăţarea şi igienizarea aparatelor ortodontice mobile? (Întrebare pentru purtătorii de aparate ortodontice mobile)

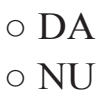

\section{REZULTATE}

În lotul de studiu au existat atât pacienți cu aparate ortodontice fixe (19) - Fig. 1, 2, cât şi cu aparate mobile (11):
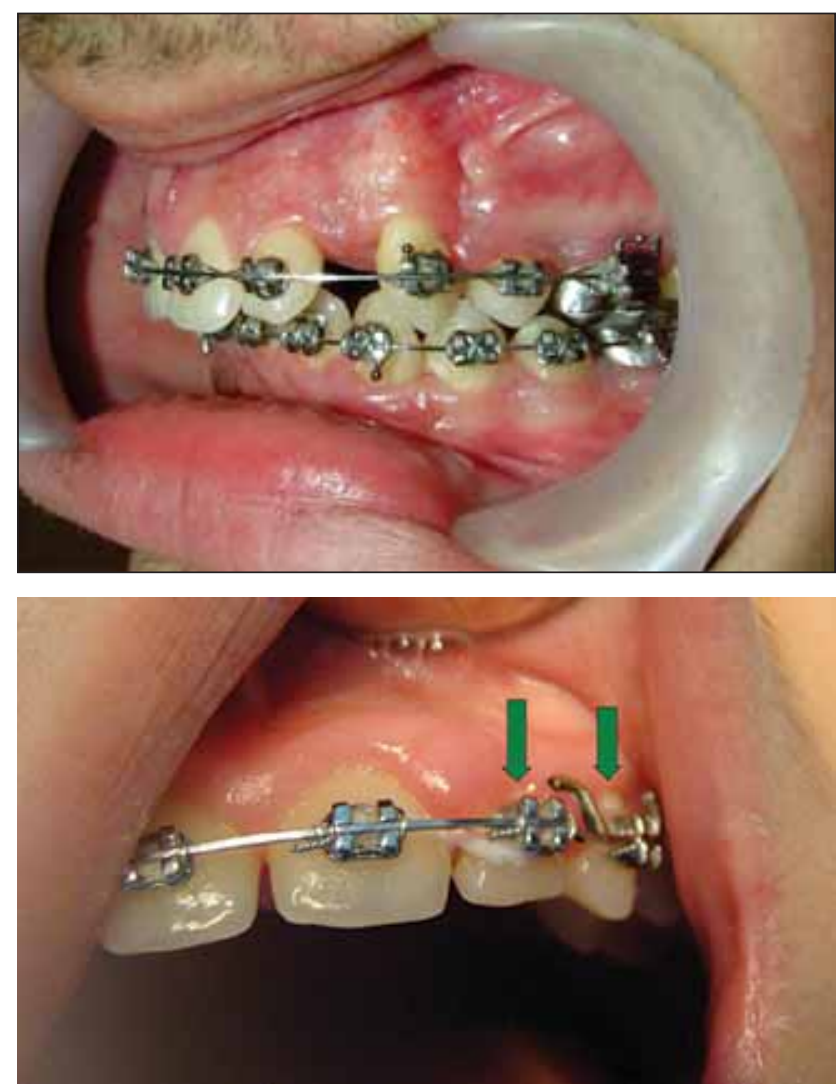

FIGURA 1 şi 2. Aparate ortodontice fixe la pacienții din lotul de studiu. Se observă acumulări de placă şi leziuni gingivale (săgeți)
Acumularea de placă bacteriană pentru cele două loturi de pacienți a fost determinată cu ajutorul indicelui Silness \& Löe. Valorile medii ale indicelui de placă sunt redate pe subloturi (sexe, tipuri de aparate) şi comparativ cu lotul martor (Fig. 3, 4).

Răspunsurile la întrebările din chestionar au fost sistematizate în Tabelul 1.

\section{DISCUŢII}

Rezultatele studiului scot în evidență două aspecte: (1) acumulări de placă bacteriană mai mari la pacienții aflați în tratament ortodontic, în special la cei care poartă aparate fixe şi (2) o grijă mai mare pentru igiena orală pentru această categorie de pacienți.

Durata şi complexitatea tratamentului ortodontic pot ridica probleme legate de exacerbarea patologiei parodontale şi carioase şi de aceea este foarte important ca medicul dentist curant să colaboreze pe parcursul tratamentului cu medicul ortodont pentru stricta monitorizare a calităţii igienei orale.

Faptul că acumularea de placă bacteriană este mai mare în cazul pacienţilor din lotul de studiu nu este o surpriză deoarece se ştie că retentivitatea naturală sau artificială a arcadelor este crescută pe parcursul tratamentului ortodontic. Din prezentul studiu reiese şi că fetele (din lotul de studiu şi din lotul martor) au prezentă mai puțină placă microbiană la nivelul dinților, probabil ca o consecință a unei mai mari rigurozități în efectuarea igienei orale. Într-un alt studiu realizat în Bucureşti, a mai fost demonstrat faptul că placa bacteriană se găseşte în cantități mai scăzute la fete (4), iar alți autori au ară-

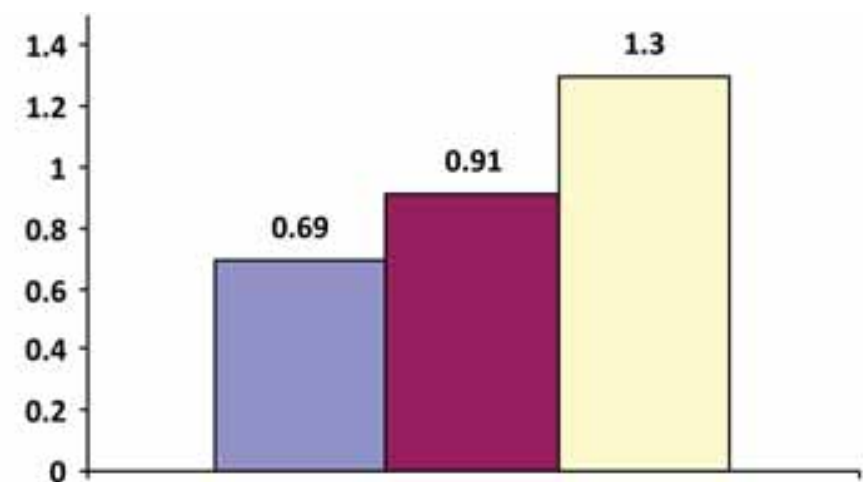

Lot martor

Purtători de aparate mobile

\section{Purtători de aparate fixe}

FIGURA 3. Valorile medii ale indicelui de placă în funcție de tipul de aparat 


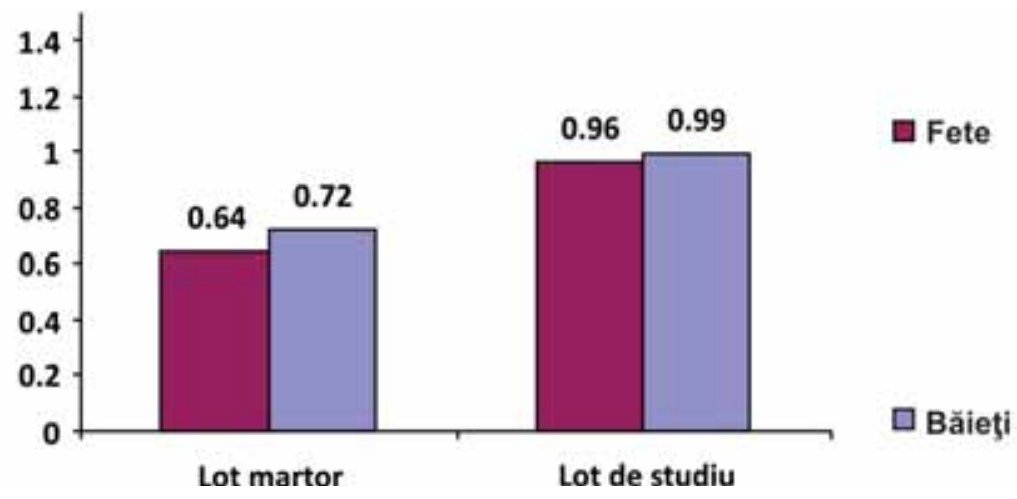

FIGURA 4. Valorile medii ale indicelui de placă în funcție de sex

TABELUL 1. Răspunsurile paciențior din cele două loturi la întrebările din chestionar

\begin{tabular}{|c|c|c|c|}
\hline \multirow[t]{2}{*}{ Întrebare } & \multirow[t]{2}{*}{ Variante de răspuns } & \multicolumn{2}{|c|}{ Răspunsuri } \\
\hline & & Lot de studiu & Lot martor \\
\hline \multirow{2}{*}{ 1. Ce periuță dentară folosiți? } & manuală & $63 \%$ & $73 \%$ \\
\hline & electrică & $37 \%$ & $27 \%$ \\
\hline \multirow{6}{*}{$\begin{array}{l}\text { 2. Ce mijloace suplimentare de igienă orală (pe lângă } \\
\text { periajul dentar) utilizați? }\end{array}$} & ață dentară (superfloss) & $20 \%$ & $38 \%$ \\
\hline & periuță interdentară & $40 \%$ & $8 \%$ \\
\hline & apă de gură & $10 \%$ & $31 \%$ \\
\hline & duș bucal & $53 \%$ & $0 \%$ \\
\hline & altceva & $7 \%$ & $8 \%$ \\
\hline & niciunul & $27 \%$ & $46 \%$ \\
\hline \multirow{3}{*}{$\begin{array}{l}\text { 3. Vă igienizați cavitatea bucală după mesele luate în } \\
\text { timpul zilei? }\end{array}$} & DA, mă spăl pe dinți & $66 \%$ & $50 \%$ \\
\hline & DA, clătesc gura cu apă & $17 \%$ & $8 \%$ \\
\hline & NU & $17 \%$ & $42 \%$ \\
\hline \multirow{2}{*}{$\begin{array}{l}\text { 4. Realizați igienizarea aparatului dentar mobil în } \\
\text { fiecare seară?* }\end{array}$} & DA & 7 & - \\
\hline & NU & 4 & - \\
\hline \multirow{2}{*}{$\begin{array}{l}\text { 5. Utilizați tablete pentru curățarea și igienizarea } \\
\text { aparatelor ortodontice mobile?* }\end{array}$} & DA & 1 & - \\
\hline & NU & 10 & - \\
\hline
\end{tabular}

*întrebări doar pentru purtătorii de aparate ortodontice mobile (răspunsurile sunt reprezentate în număr de cazuri)

tat faptul că fetele purtătoare de aparate ortodontice îşi efectuează periajul dentar mai regulat (5).

Analiza chestionarului a arătat o grijă suplimentară pentru igiena orală a purtătorilor de aparate ortodontice, fiind probabil o consecință a educației primite de pacienți din partea medicilor curanți. Procentele mai mari de utilizare a periuței electrice, a duşului bucal sau a periuței interdentare atestă acest lucru.

Pacienții aflați în tratament ortodontic trebuie educaţi suplimentar în ceea ce priveşte igiena orală. Studiile au demonstrat faptul că, dacă acestor pacienți le este reamintit periodic cât de important este să-şi realizeze igena orală regulat sau dacă vin la controale periodice pentru supravegherea igienei orale, rezultatele sunt mult mai bune în acest sens (6).

\section{CONCLUZII}

Pacienții aflați în tratament ortodontic au prezentă o cantitate mai mare de placă bacteriană la nivelul dinţilor, fapt care măreşte riscul apariţiei cariilor şi bolii parodontale. Cu o grijă mai mare pentru igiena orală şi cu o educație suplimentară în acest sens din partea medicului dentist şi a medicului ortodont, echilibrul poate fi păstrat pe parcursul tratamentului.

\section{Mulțumiri}

Mulțumim companiei Colgate-Palmolive România pentru sprijinul acordat.

Conflict of interest: none declared 


\section{BIBLIOGRAFIE}

1. Cuculescu M. Prevenţie primară în carie şi parodontopatii. Editura Didactică şi Pedagogică, Bcureşti 2010: 457-464

2. Pan S., Liu Y., Si Y., Zhang Q., Wang L., Liu J., Wang C., Xiao S. Prevalence of fimA genotypes of Porphyromonas gingivalis in adolescent orthodontic patients. PLoS One. 2017 Nov 27;12(11):e0188420

3. Thilagrani P.R., Agarwal A.P., Quadri S.M., Rajmani H., Tiwari A., Dash D. Association of Periodontal Health with Orthodontic Appliances among Indian Patients. J Int Oral Health, 2015:7(1):44-47

4. Funieru C., Klinger A., Băicuș C., Funieru E., Dumitriu H.T., Dumitriu A. Epidemiology of gingivitis in schoolchildren in Bucharest, Romania: a cross-sectional study. Journal of Periodontal Research 2017; 52(2):225-232

5. Kudirkaite I., Lopatiene K., Zubiene J., Saldunaite K. Age and gender influence on oral hygiene among adolescents with fixed orthodontic appliances. Stomatologija, Baltic Dental and Maxillofacial Journal, 2016;18:61-65

6. Cozzani M., Ragazzini G., Delucchi A., Mutinelli S., Barreca C., Rinchuse D.J., Servetto R., Piras V. Oral hygiene compliance in orthodontic patients: a randomized controlled study on the effects of a post-treatment communication. Progress in Orthodontics, 2016;17:41. 